\title{
CONTRADITÓRIO NO INQUÉRITO CIVIL COMO MODELO PARTICIPATIVO DE TUTELA COLETIVA
}

\author{
CONTRADITORY IN CIVIL SURVEY AS PARTICIPATIVE MODEL OF COLLECTIVE \\ GUARDIAN
}

\begin{abstract}
Fabrício Veiga Costa
Professor do Programa de Pós-Graduação Stricto Sensu em Proteção dos Direitos Fundamentais

Universidade de Itaúna.

Pós-Doutorado em Educação (UFMG).

Pós-Doutorado em Psicologia (Pucminas).

fvcufu@uol.com.br
\end{abstract}

\author{
Davi de Paula Alves \\ Mestrado em Proteção dos Direitos Fundamentais \\ Universidade de Itaúna. Professor Universitário \\ jurisdavi@gmail.com
}

\begin{abstract}
Resumo: O objetivo geral da presente pesquisa é revisitar a natureza inquisito-procedimental do inquérito civil público, propondo uma análise processual do respectivo instituto mediante a observância obrigatória do princípio do contraditório, visto como pressuposto jurídico da legitimidade democrática do provimento estatal. A justificativa objetiva da escolha do tema decorre de sua relevância prática, teórica e atual, especialmente porque as provas produzidas no âmbito do inquérito civil público poderão ser utilizadas na propositura da ação civil pública e na realização do termo de ajustamento de conduta. Por meio da pesquisa bibliográfica e documental, análises temáticas, teóricas, interpretativas e críticas, concluiu-se que o inquérito civil público é um modelo de processo coletivo democrático, sendo obrigatória a observância do contraditório para assegurar a legitimidade democrática do provimento estatal.
\end{abstract}

Palavras-chave: inquérito civil público; princípio do contraditório; processo coletivo democrático.

Abstract: The general objective of this research is to revisit the inquisitive-procedural nature of the public civil inquiry, proposing a procedural analysis of the respective institute through the mandatory observance of the contradictory principle, seen as a legal presupposition of the democratic legitimacy of the state provision. The objective justification for choosing the theme stems from its practical, theoretical and current relevance, especially since the evidence produced in the context of the public civil inquiry may be used in the filing of public civil action and in conducting the conduct adjustment term. Through bibliographic and documentary research, thematic, theoretical, interpretive and critical analyzes, it was concluded that the public civil inquiry is a model of a democratic collective process, with the observance of the adversary being mandatory to ensure the democratic legitimacy of the state provision.

Keywords: public civil inquiry; contradictory principle; democratic collective process.

Para citar este artigo (ABNT NBR 6023:2018)

COSTA, Fabrício Veiga; ALVES, Davi de Paula. Contraditório no inquérito civil como modelo participativo de tutela coletiva. Revista Thesis Juris - RTJ, São Paulo, v. 10, n. 1, p. 84-114, jan./jun. 2021. http://doi.org/10.5585/rtj.v10i1.16904. 


\section{Introdução}

O objetivo geral da presente pesquisa é investigar a efetivação do princípio do contraditório no inquérito civil público, haja vista a possibilidade real de utilização das provas coletadas na propositura da ação civil pública. A justificativa da escolha do tema decorre da sua relevância teórica, prática e atualidade, especialmente em razão do fato de ser comum no Brasil o Ministério Público produzir unilateralmente provas irrepetíveis na fase de inquérito e, em seguida, utilizar tais provas como fundamento das alegações na ação civil pública. Se as provas produzidas no âmbito inquisitorial não puderem ser repetidas na fase processual ter-se-á, assim, o cerceamento de defesa, limitando-se o direito de o demandado (investigado) participar de forma direta da construção do provimento final. É nesse contexto propositivo que se delimita o objeto da pesquisa, enaltecendo-se a importância do contraditório na fase de inquérito civil público, com o condão de evitar posteriormente possíveis alegações de error in procedendo, bem como evitar decisões injustas que condenam pessoas, sem que as mesmas consigam exercer com plenitude o direito constitucional de defesa e produção de provas.

Visando sistematizar o debate proposto, discutir-se-á inicialmente o princípio do contraditório no contexto das teorias do processo, recortando-se a análise proposta no estudo teórico do processo como espaço de ampla discursividade da tutela coletiva. O contraditório é visto como mecanismo de autoinclusão dos sujeitos no espaço processual de debate da pretensão deduzida. Para isso, a teoria das ações coletivas como ações temáticas foi utilizada como norte interpretativo para demonstrar a importância e indispensabilidade de observância do contraditório no inquérito civil público, como meio de democratizar a formação dialógica do provimento final de mérito. É por isso que se propõe a ampliação ou aumento da atuação do cidadão e da coletividade na tomada de decisões estatais, mediante participação na construção da causa de pedir da ação civil pública. A pesquisa toma por base a Constituição da República Federativa do Brasil de 1988, que estabelece parâmetros de desenvolvimento democrático do espaço processual, bem como garante ao cidadão o pleno acesso à tutela jurídica, seja ela de origem individual ou coletiva.

Discutir-se-á inicialmente o modelo de processo como relação jurídica, com menções posteriores de teorias que tentaram superá-la. Sobre as teorias analisadas, é abordada a sua aplicabilidade ao sistema jurídico-constitucional vigente. A assimilação do conceito de contraditório que corresponde aos parâmetros trazidos pela Constituição de 1988 permitiu a realização de estudos críticos sobre a tutela coletiva de direitos no Brasil, fazendo uma abordagem comparativa dos sistemas representativo e participativo. Confronta-se o sistema 
representativo vigente no Brasil e elabora-se uma análise do modelo participativo, fazendo-se, nesse ponto, uma abordagem à luz da teoria das ações coletivas como ações temáticas. Com as conclusões extraídas dos itens apresentados, estruturou-se o terceiro capítulo, o qual abordou propriamente o inquérito civil, tendo-se como parâmetro as reflexões relativas ao modelo de contraditório adequado aos parâmetros de constitucionalidade e ao modelo de processo coletivo coerente com os pressupostos da democracia participativa. Ao final, propõe-se, em breves termos, um modelo de participação popular no âmbito do inquérito civil, com o objetivo de viabilizar a efetiva participação coletiva na construção do provimento estatal que comporte a atuação de qualquer cidadão.

É necessário encontrar maneira(s) de viabilizar a efetiva participação do cidadão, enquanto integrante da coletividade, nas tomadas de decisão estatais que versem sobre o direito transindividual, uma vez que é preciso compreender que os parâmetros constitucionais de participação popular na construção dos provimentos é conquista teórica que precisa ser colocada em prática. O tema-problema objeto da presente pesquisa circunda no seguinte questionamento: o cidadão, enquanto componente da coletividade, tem o direito de contribuir para a formação da causa de pedir da ação civil pública, mediante a observância obrigatória do contraditório no inquérito civil público? A hipótese apresentada inicialmente se baseia na assertiva de que é direito do cidadão a contribuição na causa de pedir da ação civil pública, uma vez que essa participação contribui para a formação do objeto de discussão da demanda coletiva. Porém, a confirmação dessa hipótese dependerá da construção de um modelo que consiga processar todas as manifestações dos interessados para a construção de um provimento comparticipado.

A metodologia utilizada no presente trabalho consiste na utilização de pesquisa teóricobibliográfica, com busca em literaturas nacionais e internacionais, artigos científicos, ressaltando-se que as proposições que delimitam o problema foram pautadas num raciocínio hipotético-dedutivo. Foram escolhidos três métodos de investigação das ciências sociais aplicadas, como opções de metodologia, sendo elas a investigação histórico-jurídica (investigação está concentrada nas teorias do processo e na evolução da ideia de contraditório), do tipo jurídico-descritivo e com a adoção do método jurídico-propositivo. Por meio desses instrumentos metodológicos foi possível construir análises críticas que ultrapassam o entendimento dogmático do tema apresentado. 


\section{Contraditório e a necessidade de um novo paradigma visto sob a perspectiva das teorias do processo}

A compreensão teórica do princípio do contraditório, no contexto das teorias do processo, é de significativa importância para a investigação científico-comparativa do objeto proposto. $\mathrm{O}$ enfoque principal do presente estudo se baseia na qualidade com que a tutela jurídica é oferecida aos cidadãos envolvidos em questões submetidas a julgamento pelo poder público. E nesse ponto, a utilização do termo "poder público" é proposital, visto que a preocupação da atuação estatal capaz de repercutir diretamente sobre a esfera jurídica dos cidadãos em geral ultrapassa o campo da judicialidade. Fala-se, portanto, em tutela estatal ou tutela jurídica, em vez de se falar em tutela judicial ou tutela jurisdicional, justamente com o propósito de abranger a atuação estatal como um todo. Nesse aspecto, e conforme se observará ao longo deste estudo, preocupa-se com a preservação dos princípios constitucionais e direitos do cidadão oponíveis em face do poder público de um modo geral, sobretudo porque toda resposta estatal, em quaisquer esferas, é capaz de atingir a esfera jurídica de quaisquer indivíduos e/ou de toda a coletividade.

Fala-se em qualidade da tutela jurídica sob o ponto de vista da maneira como é construído o provimento final, mais precisamente no que pertine ao grau de participação, envolvimento ou engajamento das pessoas diretamente interessadas ou afetadas. O direito processual assume um papel importante nesta abordagem, sobretudo porque o seu objeto de estudo incorpora os modos de atuação estatal para a construção do provimento final. A Constituição da República Federativa do Brasil institui o amplo acesso de qualquer cidadão à tutela estatal, seja no âmbito da judicialidade, seja no âmbito da extrajudicialidade ${ }^{1}$, posto que, para a esfera judiciária, tem-se o direito de ação, previsto no art. $5^{\circ}$, inciso XXXV, ao passo que, para os demais âmbitos, tem-se o direito de petição, previsto no inciso XXXIV, alínea "a", do art. $5^{\circ}$. Observa-se a existência de uma preocupação com a atuação estatal em toda a sua inteireza, razão pela qual é possível inferir que os modos de atuação do poder público devem seguir a mesma matriz metodológica (matriz democrático-participativa).

Com base nessas premissas, tem-se que é inadequado o estudo do inquérito civil, que, no Brasil, tem previsão constitucional, sem que haja uma abordagem específica sob a ótica da ciência processual, sobretudo no que tange à metodologia mais adequada para o alcance da tutela estatal ou do provimento final. Não é possível trabalhar a participação cidadã, ou, mais especificamente, atuação dos interessados no provimento estatal sem que se aborde o princípio

${ }^{1}$ Extrajudicialidade pode ser também entendida como não-judicialidade. 
do contraditório, razão pela qual tem-se um esforço pela melhor interpretação de tal princípio, que se manifesta como reflexo direto da teoria do processo norteadora da atuação estatal.

\subsection{Do processo como espaço de discursividade da tutela coletiva: breves apontamentos sobre as teorias do processo}

A compreensão dos fundamentos teóricos sobre o processo é de relevante importância para o entendimento do objeto de pesquisa ora investigado. Vive-se, no Brasil, a atuação estatal, principalmente no âmbito da judicialidade, pautada na teoria do processo como relação jurídica que, apesar de sua importância para a evolução do direito processual e o seu desprendimento do direito material, apresenta aporias no tocante à participação dos interessados quanto ao exercício pleno do contraditório. O precursor dessa teoria, Oskar Von Bülow, considerou que "o processo é uma relação jurídica que avança gradualmente e que se desenvolve passo a passo" (BÜLOW, 2005, p. 6), visto que, "de um lado, o tribunal assume a obrigação concreta de decidir e realizar o direito deduzido em juízo e, de outro lado, as partes ficam obrigadas, para isto, a prestar uma colaboração indispensável e a submeter-se aos resultados dessa atividade comum" (BÜLOW, 2005, p. 6).

Visto como relação jurídica, o processo institui a subordinação das partes ao juiz, sendo este o encarregado de construir unilateralmente o provimento que as vincularão. Tem-se como caraterística importante nessa teoria a legitimidade decisória pressuposta, pautada nos atributos pessoais do julgador pois, uma vez presentes no juiz a honestidade, sabedoria, etc., a decisão proferida é legítima e apta a vincular os litigantes. Giuseppe Chiovenda, assevera que a relação jurídica entre as partes e o julgador tem como pressuposto a vontade da lei para o caso concreto (2002). Para o mencionado jurista,

\footnotetext{
o próprio processo, do mesmo passo que tem por objeto a relação jurídica entre as partes deduzida em juízo pelo autor (relação jurídica substancial), constitui por sua vez [...] uma relação jurídica de direito público entre as partes e o órgão jurisdicional (relação jurídica processual): as duas relações se apresentam no processo contínuas interferências e contraposição. (CHIOVENDA, 2002, p. 21).
}

Embora seja admitida a existência do mínimo de interação entre as partes e o julgador, não se evidencia, nos primeiros escritos dedicados à relação jurídica, uma preocupação com o valor ou com o método adequado de participação dos litigantes para a construção do provimento final. Em verdade, a participação das partes fica em segundo plano, pois a decisão jurisdicional já está amparada pelos atributos pessoais do julgador. Em termos práticos, a irrepreensibilidade da figura do julgador é que dá legitimidade à sua decisão. James Goldschmidt elabora uma 
abordagem que se contrapõe à teoria da relação jurídica, sob o argumento de que o processo se perfaz em uma situação jurídica; o processo seria formado por um conjunto de situações legalmente previstas e que, por isso, mereciam obediência por parte dos sujeitos do processo, de maneira que a procedência seria entendida como uma expectativa, e a derrota uma perspectiva (1936).

\begin{abstract}
O Direito pode ser concebido como um conjunto de imperativos que devem ser seguidos por aqueles sujeitos a regras jurídicas, também como uma série de regras que devem ser aplicadas pelo juiz. [...] Os vínculos jurídicos que surgem daqui entre as partes não são propriamente $<<$ relações jurídicas $\gg$ (consideração $<<$ estática $\gg$ da Lei), ou seja, não são poderes ou deveres no sentido de poderes sobre imperativos ou mandatos, mas $<<$ situações jurídicas $>>[\ldots]$ (consideração dinâmica do direito), ou seja, situações de expectativa, esperanças de que a conduta judicial seja produzida e, em última instância, da futura decisão judicial; numa palavra: expectativas, possibilidades e encargos (GOLDSCHMIDT, 1936, p. 8) (tradução livre)².
\end{abstract}

Contudo, observa-se que não há uma preocupação com a interação entre as partes e o juiz na construção do provimento, posto que são esquadrinhadas pela lei as situações jurídicas legitimadoras dos atos de cada sujeito processual. Uma vez deslocado para a lei, exclusivamente, o fundamento para a prática dos atos processuais, esvazia-se a possibilidade de influência dos litigantes quanto ao conteúdo decisório. Vencer, tão-somente, a ideia de relação jurídica, com a justificativa de ausência de vínculo entre os sujeitos do processo prejudica muito mais do que beneficia, na medida em que o juiz, pautado exclusivamente nas atribuições que a lei lhe confere, não se sentiria, de forma alguma, vinculado aos atos praticados pelas partes para a elucidação dos fatos e questões postos em debate, sobretudo em razão de se saber que a lei não é capaz de exaurir todas as possibilidades de ação ou abstenção das partes, nem mesmo fatos ou circunstâncias peculiares ocorríveis de acordo com o caso concreto.

No Brasil, a difusão da teoria do processo como relação jurídica teve como característica o acréscimo dos escopos do processo, como se o processo tivesse que atender a escopos, ou finalidades específicas. Cândido Rangel Dinamarco, nessa perspectiva, entende que o processo teria finalidades políticas, sociais e jurídicas, sendo o escopo social calcado na necessidade de se promover a paz social, em razão do que o Estado se encarregaria de eliminar os chamados estados de insatisfação; observa-se, ainda, como escopo social a educação, na medida em que a atuação jurisdicional serviria como um meio de educar as pessoas no sentido de respeitar os direitos alheios, bem como de se exercer os próprios direitos (2013). Tem-se como escopo

\footnotetext{
${ }^{2}$ Puede concebirse el Derecho como un conjunto de imperativos que han de seguir los sometidos a las reglas jurídicas, pelo también como una serie de normas que han de ser aplicadas por el juez. [...] Los vínculos jurídicos que nacen de aqui entre las partes no son propriamente $\langle<$ relaciones jurídicas $>>$ (consideración <<estática〉> del Derecho), esto es, no son facultades ni deberes en el sentido de poderes sobre imperativos o mandatos, sino <<situaciones jurídicas〉> [...] (consideración dinâmica del derecho), es decir, situaciones de expectativa, esperanzas de la conducta judicial que há de producirse y, en último término, del fallo judicial futuro; en una palabra: expectativas, posibilidades y cargas (GOLDSCHMIDT, 1936, p. 8).
} 
jurídico "a atuação da vontade concreta do direito" (DINAMARCO, 2013, p. 139), ao passo que o escopo político consiste em fortalecer a jurisdição, de maneira a que esta tenha cada vez mais credibilidade (2013), como se a mesma fosse o meio derradeiro de efetivação da justiça.

Nesse contexto propositivo, o contraditório não é colocado em primeiro plano, quando se observa o desenvolvimento da teoria da relação jurídica. Em verdade, o contraditório aparece com maior evidência a partir dos estudos de Elio Fazzalari, que considerou que "[...] o processo é um procedimento do qual participam (são habilitados a participar) aqueles em cuja esfera jurídica o ato final é destinado a desenvolver efeitos: em contraditório, e de modo que o autor do ato não possa obliterar as suas atividades (FAZZALARI, 2006, p. 118-119). Contraditório, para Fazzalari, passa a ser o elemento que dá qualidade ao procedimento, tornando-o um processo. Ou seja, sem contraditório, não se fala em processo, mas sim em procedimento, razão pela qual o procedimento passa a ser entendido como um gênero, e o processo uma espécie, conforme entende Aroldo Plínio Gonçalves:

O processo começará a se caracterizar como uma "espécie" do "gênero" procedimento, pela participação na atividade de preparação do provimento, dos "interessados", juntamente com o autor do próprio provimento. Os interessados são aqueles em cuja esfera particular o ato está destinado a produzir efeitos, ou seja, o provimento interferirá, de alguma forma, no patrimônio, no sentido de universum ius dessas pessoas (GONÇALVES, 2012, p. 93).

O elemento qualificador do procedimento (contraditório) se efetiva, para Fazzalari, quando as partes têm a oportunidade de, em simétrica paridade, participar e contribuir para o resultado do procedimento (2006). O procedimento, por sua vez, se traduz em uma atividade preparatória que objetiva a produção de um ato estatal (2006). A partir de Fazzalari é que se passa a pensar em processo para além da judicialidade, posto que em qualquer procedimento tendente à preparação de um ato, decisão ou provimento final, pode existir a atuação dos interessados, em simétrica paridade. Tal consideração é de grande valia, sobretudo nos estudos relativos às tutelas coletivas, principalmente pelo fato de a estrutura normativa infraconstitucional brasileira, para a proteção de direitos coletivos, estabelecer uma porção de legitimados, na condição de representantes das coletividades, para a propositura da ação civil pública, de modo que o cidadão, por exemplo, ou o conjunto de cidadãos que se mostrem diretamente afetados pelo objeto da controvérsia, tem cerceada a possibilidade de participar da construção do provimento final. Nesta senda, considerando as lições fazzalarianas do conceito de processo, é possível vislumbrar uma possibilidade de participação popular pré-jurisdicional, mediante um procedimento conduzido pelo representante da coletividade (Ministério Público), de modo a proporcionar uma tomada de decisão comparticipada que, na hipótese, poderia 
constituir a própria causa de pedir da ação coletiva. Ter-se-ia, deste modo, uma alternativa à impossibilidade normativa de participação popular na ação civil pública.

O Ministério Público, na sua atribuição de proteger direitos difusos e coletivos, tem em seu favor, nos termos do art. 129, inciso III, da Constituição da República Federativa do Brasil ${ }^{3}$, a possibilidade de utilizar o inquérito civil ou a ação civil pública. Entretanto, a menção a essa questão se mostra importante no momento em que analisa a teoria do processo trazida por Elio Fazzalari, principalmente por ser possível considerar que, tanto no inquérito civil quanto na ação civil pública, poder-se-á falar em processo, com a obrigatoriedade de observância do contraditório. Significa considerar que, se, no inquérito civil, que é, em princípio, procedimento preparatório para um possível ajuizamento de ação civil pública, as pessoas diretamente afetadas participarem da construção dos elementos preparatórios, de modo a elucidar as questões fáticas e jurídicas elementares para o alcance da verdade, contribuindo, nesta senda, para que o Ministério Público conclua pela necessidade ou não de ajuizamento da ação civil pública, estar-se-á falando em processo, mesmo que não seja jurisdicional. Essa é a proposta central da presente pesquisa: ressignificar a natureza jurídico-inquisitiva que caracteriza o inquérito civil público para, assim, apresentar uma proposta de cunho processual para o entendimento do referido tema, cuja observância do contraditório passa a ser vista como obrigatória.

Entretanto, há que se fazer uma crítica à teoria em razão do fato de sua estrutura se basear, de certo modo, nos fundamentos que também dão esteio à teoria do processo como relação jurídica. Isto se deve ao fato de que, na teoria de Fazzalari, cabe ao juiz conceder às partes a paridade de armas necessária para o efetivo exercício do contraditório. Pode-se, com isto, dizer que ainda se encontra nas mãos do juiz, tal como prelecionado pela teoria de Bülow e seus adeptos, a prerrogativa de conduzir soberanamente o processo. Embora seja considerada um avanço, a teoria não foi capaz de desfazer o protagonismo judicial, razão pela qual não se pode afirmar que a teoria fazzalariana seja suficiente para corresponder aos fundamentos da Constituição do Brasil de 1988, a qual atribui ao povo (e ao cidadão) a força da qual emanam todas as formas de atuação do Estado, razão pela qual deve ser sobrepujada a ideia de protagonismo do juiz no exercício da atividade jurisdicional.

${ }^{3}$ Constituição. Art. 129. São funções institucionais do Ministério Público: [...] III - promover o inquérito civil e a ação civil pública, para a proteção do patrimônio público e social, do meio ambiente e de outros interesses difusos e coletivos; 


\subsection{Contraditório como mecanismo de autoinclusão no espaço processual}

Com base nas considerações anteriores, evidencia-se a necessidade de se visualizar um modelo de processo que tenha como prioridade o envolvimento, participação e engajamento das partes para a construção do provimento final. Nesta ótica é que se torna importante trabalhar o modelo de processo como espaço de discursividade, que, tendo raiz neoinstitucionalista, considera a necessidade de participação de todos os interessados na construção de qualquer decisão final, seja jurisdicional ou pré-jurisdicional. Andrea Alves de Almeida considera que o espaço processualizado "é recinto de discursividade proposicional (conjectura testificada aberta à crítica incessante) e legítimo da metalinguagem" (ALMEIDA, 2011, p. 56), que não permite a utilização de metodologias que impeçam ou inviabilizem a refutação, a argumentação, o debate e a participação dos interessados. É garantido a todos os envolvidos o direito a igual interpretação a respeito das questões objeto do debate ou da controvérsia. Esse direito a igual oportunidade de interpretação é chamado de isomenia, que, para Rosemiro Pereira Leal, atende melhor à necessidade de participação popular, diante da insuficiência da isonomia que, para ele, só ocorre no campo espacial.

É que o dogma de que "todos são iguais perante a lei" que vinca, por séculos, o direito liberal, é entendido no sentido de que essa igualdade interpretativa é isotópica (espacial), mas cognitivamente assimétrica, uma vez que o Estado-juiz não está adstrito à existência de normas escritas específicas e tipificadoras para decidir em todas as hipóteses dos conflitos humanos, o que torna a argumentação das partes inócua, porque, nessa hipótese, as partes não participam isomenicamente da construção do provimento (LEAL, 2017, p. 319).

A concepção de processo como espaço constitui uma superação ao modelo hegemônico da relação jurídica, posto que não se trabalha a ideia de hierarquia entre as partes e o juiz, razão pela qual o exercício do contraditório não depende da concessão, pelo juiz, como se fosse ele o encarregado de "conceder" às partes a possibilidade de fala. Contraditório, entendido como princípio, confere ao interessado a capacidade de autoinclusão no espaço de debate, característica essa que transforma o procedimento em um verdadeiro processo participativo e democrático. A legitimidade decisória não está pautada nas atribuições pessoais do juiz; ou seja, o juiz não se pauta em sua sabedoria inata, ou na sua estima ou condição de pessoa superior, visto que a autoinclusão e a participação isomênica de todos os envolvidos é que torna legítimo o provimento final. Nessa esteira, o provimento final se torna fruto de construção conjunta entre todos os envolvidos, apresentando a característica da objetividade. Aliás, Dhenis Cruz Madeira trabalha a ideia da incompatibilidade entre o conhecimento 
subjetivo e o espaço processual, sobretudo em razão da impossibilidade de refutação àquilo que é subjetivo.

O que se quer dizer, para que fique mais claro, é que o discurso processual é incompatível com o conhecimento subjetivo, eis que este, por habitar somente na mente do ser pensante, é impassível de crítica e, portanto, do contraditório. Por isso, os argumentos de cunho estritamente moral ou mesmo argumentos de cunho puramente filosóficos - e que, portanto, tendem à subjetividade e não guardam relação direta com alguma norma jurídica - são impassíveis de utilização no discurso processual (MADEIRA, 2012, p. 371).

Fabrício Veiga Costa trabalha a ideia de processo como espaço na perspectiva das tutelas coletivas, mediante a consideração de que, assim como nas tutelas individuais, as tutelas coletivas devem estar baseadas na participação efetiva dos cidadãos, posto que eles é que sofrerão os efeitos diretos do provimento estatal.

\begin{abstract}
Os espaços de interlocução são vistos como locus de formação de opiniões dos cidadãos por meio de redes de discussões que visam construir o consenso coletivo e a gestão dos dissensos, oferecendo subsídios, conteúdos e critérios para deliberações participadamente tomadas e que venham a atender o interesse da coletividade. Além do princípio da participação ser visto como a viga mestra do Estado Democrático de Direito, sabe-se que os fundamentos genuínos de uma democracia se encontram na legitimidade de controle dos cidadãos dos atos praticados pelo Estado e que versam direta ou indiretamente sobre os direitos da coletividade. Trata-se de um exercício difuso e contínuo praticado pelos sujeitos legitimados ao processo coletivo, e não por um mecanismo de escolha dos representantes municiados de legitimidade para levantar demandas e apresentar propostas de soluções que versam sobre direitos metaindividuais (COSTA, 2012, p. 209).
\end{abstract}

O modelo de processo coletivo como locus possibilita o empoderamento do cidadão, na medida em que se traduz em metodologia jurídico-constitucional de enfrentamento das questões individuais e transindividuais, com abrangência nos procedimentos de ordem jurisdicional, administrativa ou legislativa, bem como os procedimentos não-jurisdicionais ou préjurisdicionais. Surge, nesta ótica, um desafio a ser alcançado pela ciência processual brasileira, visto que no âmbito das tutelas coletivas, assim como na tutela individual, todos os interessados têm o direito de participação na construção do provimento. Em se tratando de tutelas coletivas, imaginar uma participação de todos os interessados poderia, em princípio, implicar em uma multitudinaridade lesiva à efetividade processual. Por esta razão se impõe o enfrentamento do processo coletivo sob o enfoque constitucional e participativo, por meio da proposição de um modelo calcado no locus de efetivação do contraditório, sem que a participação dos juridicamente interessados prejudique a efetividade, ao mesmo tempo que atenda ao paradigma de Estado Democrático de Direito estatuído na Constituição vigente 


\section{Processo Coletivo: da representatividade ao sistema participativo}

O estudo dos fundamentos teóricos do processo coletivo é de fundamental relevância para a investigação da proposta de pesquisa apresentada. É importante, para a abertura deste item, reforçar o objetivo principal do presente estudo, que é a adequabilidade, ou não, da visão do inquérito civil instaurado sob o crivo do contraditório, sendo este considerado o princípio processual viabilizador da participação autoinclusiva e isomênica de todos os interessados e afetados pela tutela jurídica traduzida pelo provimento final.

De igual maneira, mostra-se necessária a dedicação dos esforços do presente estudo na tutela coletiva, posto que se impõe a busca de uma maneira de atuação de todos os interessados, sem que o processo perca a sua efetividade. Processo, aqui, é visto de uma forma ampla, de tal ponto a ultrapassar o campo da judicialidade. Antes de se adentrar, especificamente, na seara do inquérito civil (visto aqui como instituto investigatório precedente da ação coletiva), importa analisar a ação civil pública no que se relaciona à adequabilidade do modelo vigente, sobretudo quanto à participação efetiva daqueles que serão afetados pelo provimento final. Nesse rumo, já se observa uma questão de grande preponderância e que conflita nitidamente com a ideia de processo como espaço de discursividade: a exclusão do cidadão do rol de legitimados ativos da ação civil pública, mesmo restando claro que toda coletividade será afetada diretamente pelos efeitos jurídicos provimento final de mérito.

\subsection{A exclusão do cidadão na sistemática processual coletiva brasileira}

O primeiro registro que se observa, no ordenamento jurídico brasileiro, relativo à tutela processual de direitos coletivos, está contido na Constituição do Império de 1824, a qual instituiu a ação popular (COSTA, 2012). Atualmente a ação popular se encontra prevista na Constituição de 1988, constituindo-se mecanismo jurídico de defesa contra atos que impliquem em lesividade ao patrimônio público ou de entidade que conte com a participação do Estado, bem como para a defesa de atos que violem a moralidade administrativa, o meio ambiente ou o patrimônio histórico e cultural. Embora a ação popular tenha como legitimado ativo o cidadão, da forma como foi regulada infraconstitucionalmente (pela Lei $\mathrm{n}^{\circ} 4.717 / 1965$, vigente e recepcionada pela Constituição de 1988) não atende aos parâmetros democráticos de participação efetiva, posto que a participação do cidadão se exaure com o ajuizamento da ação. Além disso, não há envolvimento ou engajamento da coletividade interessada na fase de elaboração da petição inicial, nem mesmo a abertura para posterior atuação da coletividade na 
definição dos pontos de controvérsia. Não há garantia de influência dos interessados difusos e coletivos na construção das questões de mérito.

A atuação do cidadão, no âmbito da ação popular, além de ser individual, se encerra no campo da oportunidade de fala, sem a garantia de que essa fala seja submetida a um amplo espaço de discursividade isomênica. Para além da ação popular, a ação civil pública se apresenta como um meio processual de tutela de direitos metaindividuais mais abrangente, ao menos sob o ponto de vista dos bens jurídicos passíveis de proteção jurídica. Nos moldes da lei de regência, a saber, Lei no 7.347/1985, a ação civil pública se prestava inicialmente à proteção de um rol de direitos que se resumia ao meio ambiente, ao consumidor e aos bens e direitos de valor artístico, estético, histórico, turístico e paisagístico. Porém, com o advento da Constituição de 1988, a ação civil pública se tornou mais abrangente, pois passou a proteger também o patrimônio público e social, o meio ambiente, bem como outros direitos difusos e coletivos. Ou seja, em razão da ampliação prevista na Constituição de 1988, quaisquer direitos transindividuais passaram a ter a possibilidade de serem discutidos por meio da ação civil pública. Contudo, a lei de regência da ação civil pública estabelece um rol taxativo de legitimados ativos, dentre os quais o cidadão não está incluído. O Ministério Público, dentre todos os legitimados, é o mais privilegiado, sobretudo por ter a seu favor a possibilidade de se utilizar do inquérito civil para a investigação pré-jurisdicional, com o objetivo de reunir elementos mínimos para o ajuizamento da ação.

Adotou-se, no Brasil, no âmbito da ação civil pública, o sistema representativo como forma de proteção dos direitos de ordem metaindividual, razão pela qual, em vez de se prestigiar a participação do cidadão, preferiu-se a eleição de uma porção de legitimados para representar toda a coletividade, sem que haja algum mecanismo efetivo de intervenção da coletividade sobre os pontos relevantes de debate. Esse sistema representativo tem, em grande parte, influência da teoria da relação jurídica, sobretudo porque a tutela de direitos metaindividuais no Brasil decorreu de uma adaptação dos instrumentos de tutela de direitos individuais. Embora defensor do sistema representativo atual, Rodolfo de Camargo Mancuso reconhece, sem deixar, entretanto, de enaltecer a estrutura vigente, que o Brasil não desenvolveu um sistema autônomo de tutela jurídica de direitos transindividuais:

Se é verdade que, a despeito dessa expressiva produção legislativa, não se chegou ainda a alcançar um vero Sistema (ou Código) Processual Coletivo, ao menos se alcançou um regime de razoável integração-complementaridade das normas que regem as ações coletivas, as quais repercutem entre si em modo de vasos comunicantes [...] (MANCUSO, 2012, p. 63). 
Nesse mesmo raciocínio, Zavascky classificava a Lei de ação civil pública como um importante regramento pátrio, instituidor de um subsistema:

Mais que disciplinar um novo procedimento qualquer, a nova Lei veio inaugurar um autêntico subsistema de processo, voltado para a tutela de uma também original espécie de direito material: a dos direitos transindividuais, caracterizados por se situarem em domínio jurídico não de uma pessoa ou de pessoas determinadas, mas sim de uma coletividade (ZAVASKY, 2017, p. 36).

Observa-se que, se fosse realmente um conjunto normativo suficiente para atender aos parâmetros atuais e as demandas transindividuais brasileiras, o sistema atual não seria denominado subsistema ou microssistema. A nomenclatura amplamente utilizada para definir a estrutura jurídico-normativa atual já demonstra que o país precisa desenvolver um modelo de proteção dos direitos transindividuais de forma mais adequado. Não significa, embora sejam tecidas as críticas ora apresentadas, que os institutos até então criados no Brasil sejam desprovidos de uma certa qualidade, ou que não representem um esforço benevolente pelo atendimento às premissas constitucionais vigentes. Entretanto, o que se pretende é a proposição de uma forma de interpretação da norma jurídico-constitucional, de modo a promover um avanço no tratamento coletivizado dos direitos, o que somente ocorrerá no momento em que se submeter a críticas e testificações das estruturas utilizadas e defendidas cotidianamente de forma hegemônica. Constata-se que a sistemática atual de tutelas coletivas é referendada por um corpo de juristas que contribuíram para a estruturação de todo o regramento processual pátrio, sobretudo no direito individual. Grande parte deles, influenciada pela teoria do processo como relação jurídica (de origem liberal e individualista), foi convocada para contribuir para a estruturação das tutelas coletivas brasileiras mediante a elaboração da lei da ação civil pública.

\begin{abstract}
Mas, inegavelmente, foi a Lei 7.347/85 o instrumento que alavancou o processo coletivo brasileiro, dando-lhe contornos mais definidos, e ensejando os desenvolvimentos e progressos que viriam na sequência; ao propósito daquela lei, cabe lembrar os Professores da USP que participaram ativamente dos trabalhos preparatórios, como Ada Pellegrini Grinover, Kazuo Watanabe, Cândido Rangel Dinamarco, Antonio Magalhães Gomes Filho, Waldírio Bulgarelli, Fábio Nusdeo, Paulo Salvador Frontini, com o apoio de juristas do porte de José Carlos Barbosa Moreira, Waldemar Mariz de Oliveira Júnior, Paulo Affonso Leme Machado, René Ariel Dotti, devendo ressaltar-se a fecunda contribuição prestada pelo Ministério Público paulista, com Nelson Nery Junior, Antonio Augusto Mello de Camargo Ferraz, Édis Milaré, Hugo Nigro Mazzilli, Antônio Herman de Vasconcellos e Benjamin, José Emmanuel Burle Filho (MANCUSO, 2012, p. 60-61).
\end{abstract}

Veja-se que a coletividade não tem a prerrogativa sequer de influir na definição do conjunto de bens jurídicos ou direitos a serem defendidos no âmbito da tutela coletiva conduzida, por exemplo, pelo Ministério Público. Isso porque a causa de pedir da ação coletiva é formada com base nas convicções unilaterais e exclusivas do legitimado ativo, sem a 
necessidade ou obrigatoriedade de consulta prévia da coletividade afetada direta ou indiretamente pelos efeitos do provimento final de mérito. Enquanto na tutela individual, considerando exclusivamente, aqui, a fase postulatória da ação judicial, o problema da participação do legitimado não se evidencia, eis que, em se tratando de direitos individuais, a legitimação é conferida, em regra, ao próprio titular do direito (razão pela qual a causa de pedir coincidirá com os interesses da própria pessoa legitimada), na tutela coletiva evidencia-se o problema da falta de participação daqueles que sofrerão os efeitos da decisão final.

Isto posto, é possível asseverar que são dois os grandes problemas provocados pelo liberalismo processual que influenciou na construção teórico-jurídica do sistema representativo atual: o primeiro, em razão da ausência de participação popular no curso da ação coletiva, provocada pela privação da possibilidade de contribuição dos cidadãos, de um modo geral, na construção do provimento final; e o segundo, em razão da ausência ou inexistência de participação da coletividade na construção da própria causa de pedir da ação coletiva.

\subsection{Ações temáticas como mecanismo de participação popular na ação coletiva}

Tem-se como pressuposto do presente item a disposição constitucional que estabelece que o poder estatal emana do povo (art. $1^{\circ}$, parágrafo único $)^{4}$, e esse poder pode ser exercido por ele de forma direta ou por meio de representantes eleitos. Observa-se que o constituinte se preocupou em estabelecer, no primeiro artigo do texto, a previsão de que o poder público, em todas as suas esferas, não deve se esquivar da premissa fundante da República brasileira, que está pautada na soberania popular. Vê-se, em outros termos, que a disposição contida no art. $1^{\circ}$, parágrafo único, da Constituição da República se dirige ao próprio poder público, o qual não tem a prerrogativa de objetar, em quaisquer que sejam as suas atividades com repercussão direta e indireta sobre a coletividade em geral, a participação dos interessados para a construção do provimento estatal. Com o intuito de buscar um meio de alcance da participação popular direta no âmbito da tutela jurisdicional, Vicente de Paula Maciel Júnior desenvolveu a teoria das ações coletivas como ações temáticas, trazendo importantes inovações para a tutela de direitos transindividuais.

Em seus estudos, há uma preocupação inicial de desmistificar a ideia de interesse público. Para o mencionado autor, "a expressão interesse público é inconcebível em um sistema democrático que pressuponha a vinculação dos agentes políticos ao consenso estabelecido pela norma" (MACIEL JÚNIOR, 2006, p. 60). O referido autor ressalta que interesses e direitos não

${ }^{4}$ Constituição. Art. $1^{\circ}$. Parágrafo único. Todo o poder emana do povo, que o exerce por meio de representantes eleitos ou diretamente, nos termos desta Constituição. 
podem ser confundidos, "visto que os primeiros [(interesses)] sempre serão manifestações individuais de vontade, enquanto os direitos pressuporão sempre um processo social de validação e reconhecimento da legitimidade dos interesses manifestados” (MACIEL JÚNIOR, 2006, p. 43). Nessa perspectiva, não existiria o interesse público ou o interesse coletivo, visto que a ninguém é dado externar uma vontade que corresponda, de fato, a toda a coletividade. Os interesses, na visão de Vicente de Paula, se relacionam com os direitos e se posicionam em um momento anterior à produção do direito. Os direitos, assim, seriam o produto de um processo de validação das manifestações de interesses.

\begin{abstract}
O fato de os interesses estarem na base de formação dos direitos não significa que eles se confundam com o próprio direito. Poderíamos falar com tranqüilidade que todo direito possui em seu processo de formação um interesse, mas nem todo interesse gerará a formação de um direito. Portanto, concluímos que os interesses e os direitos são conceitos diferentes, mas se inter-relacionam de modo íntimo. Os interesses são a base a partir da qual haverá a manifestação do sujeito e ocorrerá o desencadeamento do processo social ou judicial de validação dos interesses e a sua transformação em direitos. Os direitos, são, por sua vez, as situações jurídicas reconhecidas por um processo de validação de interesses manifestados perante a sociedade ou perante o Estado-juiz (MACIEL JÚNIOR, 2006, p. 44).
\end{abstract}

Partindo-se da premissa de que os direitos são decorrentes de um processo de validação e que não é possível que se fale em interesses coletivos, já que as vontades ou interesses da coletividade assumem um caráter polissêmico, verifica-se que os adeptos da representação adequada ou do sistema representativo enfrentam um problema que parece não ter solução: se não existe interesse coletivo e se os direitos coletivos pressupõem um processo de validação, de onde são extraídas as convicções dos legitimados ativos para a construção da causa de pedir de uma ação coletiva? ${ }^{5}$ Juliana Maria Matos Ferreira (2011) relembra as diretrizes constitucionais de acesso à justiça/inafastabilidade da jurisdição para esclarecer que não há razão constitucional para que os interessados difusos sejam excluídos da possibilidade de participação efetiva, na condição de legitimado, do espaço processual.

\footnotetext{
${ }^{5}$ Os defensores do sistema representativo não oferecem resposta democrática a esse questionamento.
} 


\begin{abstract}
Ao estabelecer a inafastabilidade de apreciação pelo Judiciário de lesão ou ameaça a direito, não restringiu o constituinte referido direito apenas às ofensas individuais, mas também às ofensas coletivas, ambas constitucionalmente asseguradas. [...] Se o acesso à Jurisdição é amplo e irrestrito, segundo preleciona o direito de ação constitucionalmente assegurado, torna-se essencial a utilização do processo na criação e reconstrução permanente de institutos jurídicos. As bases teóricas utilizadas na construção do procedimento individual, consideradas atualmente ultrapassadas, tendo em vista a constante necessidade de revisitação dos conteúdos dos conceitos, são utilizadas para a construção do procedimento coletivo. O estudo do processo individual brasileiro, com intuito de alcançar escopos metajurídicos, em que a jurisdição e o processo são vistos como instrumento de realização de valores sociais e políticos da nação, [...] encontra-se superado e não deve ser direcionado para o processo coletivo (FERREIRA, 2011, p. 78).
\end{abstract}

Há um esforço de superação do clássico modelo de enfrentamento das questões processuais em matéria coletiva, que sempre teve o foco nos sujeitos do processo. Isto porque

\begin{abstract}
A ação coletiva para a tutela de direitos difusos deve ter como ponto referencial o fato que afeta a um número $\mathrm{X}$ de interessados. Não é a qualidade ou o número de sujeitos que transforma a ação em coletiva ou não. É o fato de a demanda atingir um fato e um bem sobre o qual a tutela judicial vai incidir e poder envolver um grande número de interessados. A definição judicial sobre o fato que atinge um número grande de interessados revela que a demanda é coletiva. (MACIEL JÚNIOR, 2006, p. 173).
\end{abstract}

A premissa inicial de que a participação de todo e qualquer interessado difuso seja indispensável à tutela jurídica democrática não se compatibiliza o modelo de processo coletivo atual, demarcado/estremado nos sujeitos (autor e réu), centrado na premissa dogmática de que a inclusão de toda uma coletividade em um dos polos tornaria o processo multitudinário e impraticável. A sistematização do processo individual é estruturada nos sujeitos, justamente em razão de se partir da premissa de que a pessoa do legitimado, em regra, corresponde à pessoa cujo interesse é posto em debate. No processo coletivo, essa correspondência não existe, uma vez que não se debatem interesses e, sim, direitos advindos de um processo de validação que se opera em um espaço de discursividade metalinguística norteada pela hermenêutica isomênica.

Vicente de Paula Maciel Júnior considera que "as tentativas de explicação do fenômeno coletivo (difuso) e do processo coletivo não devem ter como ponto referencial os sujeitos, mas o fato, o acontecimento, o bem da vida que se pretende tutelar e que revelará que aquela demanda possui natureza coletiva lato sensu” (MACIEL JÚNIOR, 2006, p. 174). Além disso, "as tentativas de enquadramento do problema segundo o paradigma de processo civil individual são insuficientes e frustrantes, porque consideram o critério segundo o qual a titularidade da ação é dada a quem é o titular de um direito" (MACIEL JÚNIOR, 2006, p. 174). Com enfoque na necessidade de validação, Vicente de Paula traça linhas gerais de um modelo participativo de processo, que retira do seu eixo as partes (demandante versus demandado) e estabelece um novo parâmetro: o tema. Dessa maneira, a temática a ser enfrentada é que definirá o(s) grupo(s) 
de interessado(s) que deverão participar do debate. Para Vicente, os temas são os "fatos ou situações jurídicas que afetam os interessados" (MACIEL JÚNIOR, 2006, p. 178). Ajuizada a ação, inicia-se a fase de formação do objeto da lide, que não é definido isoladamente pelo autor da ação; a definição do objeto da lide se dará por meio da abertura, à coletividade, da possibilidade de manifestação mediante a publicação de editais. Em seguida, após o encerramento das possibilidades de manifestação por quaisquer interessados, tem-se a fase saneadora, em que o juiz fixa os pontos controvertidos, a fim de viabilizar a instrução e o julgamento do feito.

Preocupado com a celeridade e efetividade processual, Fabrício Veiga Costa considerou ser desnecessária a manifestação direta de todos os interessados no processo, bastando a filiação aos temas que correspondam aos interesses do legitimado (2012, p. 227). Assim, bastaria que o legitimado difuso aderisse a uma das temáticas postas em debate, ou, melhor dizendo, a um grupo temático, o que facilitaria o manejo e o transcurso dos atos processuais convergentes à formação discursivo-participada do provimento final. Nessa toada, tem-se uma estrutura calcada em três eixos, compostos pelas fases técnica ou preliminar, bem como as fases saneadora e instrutória (2012, p. 228). Eis, portanto, uma proposta participativa de tratamento dos direitos metaindividuais no âmbito jurisdicional. Entretanto, tal proposta não enfrenta o segundo problema evidenciado no item anterior, consistente na ausência de participação da coletividade na construção da própria causa de pedir da ação coletiva. Aliás, ao Ministério Público, deveriam ser aplicadas todas as diretrizes processuais dedicadas ao processo jurisdicional, posto que a deliberação, pelo órgão ministerial, de ajuizamento de uma ação coletiva, também careceria de uma validação por meio da participação de todos os interessados.

Nesta ótica, o próximo capítulo cuidará de abordar a respeito da forma como essa validação poderia ser realizada no âmbito de atuação do Ministério Público.

\section{Contraditório no inquérito civil e seus reflexos na construção da causa de pedir da ação coletiva}

Pela forma como foi percorrido o presente estudo, verificou-se que a tomada de decisão, ou o provimento final de mérito democrático, tem a necessidade de ser emanado em um espaço de participação de todos os envolvidos. Verificou-se, também, que essa participação decorre do princípio do contraditório, que se apresenta em todas as formas de atuação estatal, e não apenas na esfera jurisdicional. O Ministério Público está inserido na ideia de poder público, no sentido de que sua atuação reflete as ações do próprio Estado, razão pela qual as suas deliberações devem seguir a mesma diretriz democrático-participativa. Assim, analisar-se-á a possibilidade 
de participação popular, no âmbito pré-jurisdicional, conjuntamente com o Ministério Público, de maneira a verificar até que ponto é viável a garantia da influência do cidadão nas convicções do Promotor de Justiça ou Procurador da República na elaboração do seu parecer final ${ }^{6}$. Será, ainda, abordado, se a sua condição de representante isenta o Ministério Público de fundamentar os seus pleitos na "vontade popular", assim considerada o fruto do debate entre os interessados difusos, sobretudo as pessoas direta ou indiretamente afetadas pelas tomadas de decisões estatais que tenham repercussão direta ou indireta sobre direitos transindividuais.

\subsection{Inquérito civil como espaço de protagonismo do Ministério Público: uma herança da teoria do processo como relação jurídica}

Previsto na Constituição no art. 129, inciso III, o inquérito civil se apresenta como um mecanismo de atuação conferido exclusivamente ao Ministério Público, significando dizer que não se encontra disponível para outro ente do poder público, nem mesmo para os demais legitimados à propositura da ação civil pública. Esta circunstância importante corrobora para a assertiva de que o Ministério Público, dentre os legitimados ativos, é o que tem melhores elementos para delimitação dos direitos a serem defendidos em sede de ação civil pública, uma vez que tem a possibilidade de construir unilateralmente um arcabouço probatório ou elementos elucidativos sem a necessidade da autorização ou participação judicial dos interessados difusos e coletivos. Importante considerar que, embora exista previsão constitucional do inquérito civil, sua existência no ordenamento brasileiro se deu anteriormente, sendo de se registrar que a Lei da Ação Civil Pública - Lei no 7.347/1985 já previa este instrumento à disposição do Ministério Público. Com a instituição do inquérito civil, a atuação do Ministério Público ultrapassou o campo da judicialidade ${ }^{7}$. Significa dizer que o Ministério Público passou a ter instrumentos de ingerência nos conflitos interpessoais de interesses, com a possibilidade de, independentemente do ajuizamento de ação, viabilizar a solução do conflito. Ricardo de Barros Leonel, ressaltou, inclusive, o papel ministerial na pacificação social sem a necessidade de movimentação da máquina judiciária.

\footnotetext{
${ }^{6}$ Parecer final, aqui, é entendido como a tomada de decisão, por parte do membro do Ministério Público, com vistas a nortear a sua atuação diante do caso concreto. Se se tratar de um inquérito civil, a tomada de decisão poderá ser pelo arquivamento ou pelo ajuizamento de ação civil pública, bem como a realização de ajustamento de conduta ou expedição de recomendação. Debate-se, no parágrafo, a possibilidade de influência do cidadão justamente nessa tomada de decisão por parte do Ministério Público.

${ }^{7}$ É de se frisar que a atuação do Ministério Público, no Brasil, não se resume ao âmbito da judicialidade, sobretudo em razão de suas atribuições na esfera Criminal, que envolvem o controle externo do inquérito policial e a possibilidade de arquivamento do mesmo, caso verifique a ausência de justa causa para o ajuizamento da ação penal. Quando se fala que o Inquérito Civil possibilitou a atuação do Ministério Público para além do campo judicial, não é colocada em questão a esfera penal.
} 


\begin{abstract}
A investigação funciona como instrumento potencialmente apto para a composição extrajudicial do conflito e obtenção da pacificação social, sem o decurso do tempo e o custo (em todos os sentidos) do processo - fator, aliás, que se agrava considerando a complexidade natural das demandas coletivas, destinada, a priori, a perdurar por mais tempo e a gerar maiores dispêndios econômicos (LEONEL, 2017, p. 405).
\end{abstract}

É importante frisar, neste momento, que a assimilação do papel do Ministério Público, mediante suas atribuições institucionais, na obtenção da pacificação social, acarreta uma aproximação ideológica com a teoria do processo como relação jurídica, esboçada no Capítulo 2 e tão combatida no presente estudo, sobretudo pela carga de elevação do condutor do procedimento perante as pessoas envolvidas no conflito e que sofrerão autocraticamente os efeitos jurídicos da decisão final. Assim, a interpretação da atuação do Ministério Público, sob a ótica da relação jurídica, não traz benefícios sob o ponto de vista da processualidade democrática, eis que é incorporada, com a admissão da teoria como estrutura ideológica, a noção de dispensabilidade ou pormenorização da participação dos interessados, sejam eles individuais ou difusos. Entretanto, embora se faça, neste trabalho, forçosa crítica ao modelo de processo como relação jurídica, não se pode esquecer que tal modelo é o que vem sendo implementado até os tempos atuais, não de maneira pura, mas com a incursão pontual de novas teorias que, embora benéficas à procedimentação da tutela jurídica de direitos individuais e transindividuais, não foram capazes de sobrepujar, por inteiro, a estrutura hegemônica da relação jurídica como ideário (inadequado) de atuação estatal.

Nesta senda, é interpretado o inquérito civil como um mero instrumento em favor do Ministério Público para a persecução da paz social e da solução de conflitos. Associa-se a essa consideração a ideia de que, por ser o Ministério Público protagonista na atuação em sede de inquérito civil, as suas convicções, pautadas na concepção de sabedoria inata e de pleno conhecimento jurídico, por parte do seu membro, são suficientes para a solução das controvérsias não judiciais, razão pela qual, diante da suficiência proporcionada pelos atributos pessoais do Promotor de Justiça (ou Procurador da República), não seria necessária a participação de outrem na construção da tomada de decisão. Por isso mesmo é que o inquérito civil é visto, indevidamente, como um procedimento de natureza investigatória e inquisitiva, desvestida, portanto, da necessidade de obediência ao contraditório.

Sobre sua natureza jurídica é possível dizer que se trata de procedimento administrativo investigatório a cargo do Ministério Público, destinado à colheita de elementos de convicção para eventual propositura de ação coletiva. Não obstante sua finalidade primeira seja a colheita de informações para a propositura de ação coletiva, identifica-se nele também o escopo de elaboração eventual de compromisso de ajustamento para a solução extrajudicial do conflito coletivo (LEONEL, 2017, p. 407). 
Na visão de Raimundo Simão de Melo,

Define-se classicamente o inquérito civil como procedimento administrativo de natureza inquisitiva tendente a recolher elementos de prova que ensejem o ajuizamento da ação civil pública. [...] O inquérito civil, no entanto, não se destina apenas a colher prova para ajuizamento da ação civil pública ou outra medida judicial; ele tem, também, como importante objetivo, a obtenção de ajustamento de conduta do inquirido às disposições legais (MELO, 2002, p. 59).

Por mais que existam regramentos que delimitem, mesmo que minimamente, a procedimentação do inquérito civil, não há uma preocupação por parte da comunidade jurídica tradicional no sentido do estabelecimento objetivo dos paradigmas constitucionais concernentes à atuação do Ministério Público no âmbito do inquérito civil. É importante considerar que não se está dizendo, no presente estudo, que o inquérito civil se encontra desregulamentado. Pelo contrário: uma vez que sua previsão normativa é, sobretudo, constitucional, a sua sistematização deve seguir as diretrizes da processualidade democrática, conforme será abordado detidamente nos itens adiante. Quanto à repercussão do inquérito civil, Gregório Assagra de Almeida (2007) pontua o seguinte:

A conclusão do inquérito civil poderá conduzir: 1) o ajuizamento da ação civil pública
ou de outra ação coletiva pertinente; à realização de novas diligências
imprescindíveis; 2) à realização de audiências públicas para colher informações e
manifestações da comunidade diretamente interessada; 3) à expedição de
recomendação para quem de direito adote medidas mais adequadas e convenientes
para a melhora da eficácia quanto à proteção dos interesses massificados em geral; 4)
o arquivamento do inquérito civil, caso não haja fundamentação fática ou jurídica para
a propositura da ação civil pública ou de outra ação coletiva; 5) à designação de data
e horário para tentativa de tomada de TAC (ALMEIDA, 2007, p. 226).

Veja-se que a instauração de um inquérito civil pode provocar repercussões importantes na esfera de direitos de toda uma coletividade, a exemplo da possibilidade de realização de um TAC (Termo de Ajustamento de Conduta), ou, ainda, de ajuizamento da própria ação civil pública, e o sistema atual não inclui, para conferir legitimidade decisória às deliberações do Ministério Público, a participação popular. Com efeito, a decisão do Ministério Público, de arquivar um procedimento investigativo ou, de outro lado, ajuizar uma ação coletiva, não pode ter como fundamento convicções solipsistas extraídas única e exclusivamente no gabinete do Promotor de Justiça (ou do Procurador da República). Nesse ponto é que precisa ser (re)pensado o modo de atuação do Ministério Público, de maneira a deixar de lado o instrumentalismo, para que seja assumida a ideia de atuação baseada em um espaço processual de discursividade, sobretudo mediante a viabilização da autoinclusão da coletividade interessada. 
4.2 Processo coletivo democrático e princípio do contraditório: referenciais propositivos de revisitação da dogmática do inquérito civil

Na concepção de processo como espaço processual que, como dito, abarca todos os âmbitos de atuação estatal (judicial, pré-jurisdicional, administrativo e legislativo), impõe-se o posicionamento conceitual do inquérito civil de acordo com as premissas do Estado Democrático de Direito. Sem dúvidas, o inquérito civil constitui o mais importante mecanismo extrajudicial disponível ao Ministério Público para a defesa de direitos transindividuais. Neste sentido, sendo o inquérito um meio constitucional de investigação, deve ele ser uma ferramenta de persecução dos objetivos institucionais do Ministério Público, inclusive o de preservar o regime democrático. É necessário, desta feita, que se defina constitucionalmente a natureza jurídica do inquérito civil. Há um esforço doutrinário no sentido da caracterização do inquérito como um procedimento administrativo, mediante a defesa da ideia de desnecessidade do contraditório. Gregório Assagra de Almeida, por exemplo, defende a desnecessidade de implementação do contraditório em razão da ausência da possibilidade de imposição de sanção. Veja-se:

Não é obrigatório o contraditório no inquérito civil, tendo em vista que por esse procedimento não se visa aplicar qualquer tipo de sanção. Se ao final da apuração dos fatos o Ministério Público pudesse aplicar sanção aos responsáveis pelos danos aos direitos massificados, seria obrigatória a observância do contraditório por imperativo constitucional (art. $5^{\circ}$, LIV e LV, da CF) e, nessa hipótese, o inquérito civil passaria a ser um processo administrativo (ALMEIDA, 2007, p. 255).

Parece um tanto limitada a vinculação do contraditório à ideia pura e simples de sanção (punição), principalmente porque a sanção recai sobre a pessoa transgressora do direito transindividual objeto de debate. Além disso, o objeto do inquérito civil abrange toda a coletividade, e não apenas a pessoa do investigado. Visualiza-se, neste momento, que são mais ressaltadas, no inquérito civil, as pessoas do investigante e do investigado, e num plano subsidiário, o tema debatido (objeto da investigação). Ricardo de Barros Leonel associa o contraditório à necessidade de privação da liberdade ou de bens de uma pessoa. Por essa razão, o inquérito civil público não necessitaria observar os parâmetros institutivos do contraditório, pois o mesmo não é capaz de provocar a privação de bens ou da liberdade.

A Constituição Federal estabelece a incidência dos mencionados princípios quando haja possibilidade de privação da liberdade ou dos bens de determinada pessoa, referindo-se ao processo judicial ou administrativo e aos acusados em geral. $A$ contrario sensu, não se aplicam aquelas diretrizes constitucionais onde não haja diretamente, em decorrência do procedimento, a possibilidade de privação de bens ou da liberdade, bem como onde não haja propriamente processo judicial ou administrativo (LEONEL, 2017, p. 416). 
Defronta-se, mais uma vez, com a ideia restritiva do inquérito civil acarretada pela sua focalização nos sujeitos investigante e investigado. É um equívoco falar em (ausência de) privação de bens ou direitos quando se trata de uma investigação que envolva situações de ordem metaindividual, sobretudo porque, na sistemática atual de estruturação do inquérito civil, não há mecanismos que garantam a sondagem necessária das reais situações vividas pelos interessados diretamente afetados. A constatação da violação, ou não, de direitos metaindividuais só pode ser plenamente efetivada depois que os interessados tiverem sido, efetivamente, consultados. Ademais, é importante ressaltar que as provas coletadas unilateralmente no inquérito civil público poderão ser utilizadas para fundamentar o pedido liminar de bloqueio de bens do demandado na ação civil pública de improbidade administrativa, razão essa que evidencia a indispensabilidade do contraditório no âmbito investigativo.

A definição da natureza jurídica do inquérito civil passa pela sua associação ao paradigma de Estado Democrático de Direito e pelo modelo adequado de validação do direito a ser tutelado. Quando se fala em inquérito civil, assim como qualquer fase não jurisdicional, a discussão sobre contraditório vem sempre associada aos polos ativo e passivo, o que, sob o ponto de vista do processo individual, não é incorreto. Entretanto, quando se trata de inquérito civil, que tem como substrato um bem jurídico ou um direito de ordem transindividual, um dos polos (ativo, do investigador) age em defesa de toda a coletividade, mas não é o real destinatário do direito (ou, pelo menos, não é o único afetado). Nos moldes atuais, essa coletividade não participa ou não tem condições de convalidar ou contribuir para o direcionamento dos atos e decisões do ente encarregado de conduzir as investigações. Essa perspectiva precisa ser ampliada, a fim de que o inquérito civil incorpore, verdadeiramente, os seus elementos estruturais de constitucionalidade democrática. Nesta senda, o inquérito não pode ser visto como um mero mecanismo de investigação de uma pessoa ou grupo de pessoas, visto que os efeitos jurídicos prováveis decorrentes do inquérito civil público, por si só, demonstram a indispensabilidade de observância do contraditório.

Vislumbra-se, na presente pesquisa, a utilização do inquérito civil como um mecanismo de investigação temática. A persecução de um bem jurídico ou direito a ser protegido, na fase investigatória, sem que se encerre o espaço de discussão nas figuras polarizadas do investigante e investigado, proporciona uma mudança de paradigma de definição da natureza jurídica do inquérito civil, eis que, adotando um viés temático e considerando que os interessados difusos/coletivos são passíveis de sofrer os efeitos futuros à conclusão do inquérito, têm eles (os interessados), portanto, o direito constitucional de participação, que é pressuposto de cidadania. 
Nesse contexto propositivo, é possível inferir que a definição da natureza jurídica do inquérito civil decorre da assimilação dos seguintes pressupostos: (a) sendo mecanismo de investigação de um direito transindividual, impõe-se a necessidade de um processo de validação, que se efetiva mediante a participação dos reais interessados; $(b)$ apesar de ser um mecanismo preparatório da ação civil pública, o inquérito civil não está vinculado ao ajuizamento de ação coletiva, em razão das possibilidades extrajudiciais de solução de conflito, como ocorre no caso da elaboração do Termo de Ajustamento de Conduta - TAC, razão pela qual o inquérito civil é passível de gerar efeitos concretos sobre a coletividade ${ }^{8}$; (c) a participação popular é pressuposto de legitimidade democrática dos atos do poder público, de modo que, estando o Ministério Público, inserido nessa condição, deve praticar os seus atos com base na participação popular para construção do provimento final (que, no caso, corresponde à decisão de conclusão do inquérito, com a conseguinte elaboração da causa de pedir da ação civil pública, ou da minuta do TAC - Termo de Ajustamento de Conduta ou, ainda, da minuta da Recomendação). Isto posto, conclui-se que o inquérito civil público não pode ser visto como mero procedimento, porque ele serve para investigar o direito transindividual a ser defendido, e essa investigação depende da participação da coletividade afetada. Assim, a necessidade de participação dos interessados, para a investigação do bem jurídico a ser protegido, já faz incorporar ao inquérito civil a natureza de processo, e não de procedimento.

Compreender a investigação civil promovida pelo Ministério Público como modelo de processo coletivo democrático, evidencia a indispensabilidade de observância do contraditório, mediante a efetiva participação de todos os interessados difusos e coletivos na formação participada do provimento estatal. A proposta de participação democrática no processo coletivo, no contexto da presente pesquisa, funda-se na teoria das ações coletivas como ações temáticas. Nesse sentido, o mérito processual nas ações temáticas deve ser compreendido como um procedimento bifásico de participação dos sujeitos na formação da vontade coletiva (provimento estatal), possibilitando o direito de todos os interessados (difusos e coletivos) definirem as questões objeto de investigação e, também, construírem de forma comparticipada o relatório conclusivo no âmbito do inquérito civil público.

Atente-se, ainda, para a possibilidade de geração de efeitos independentemente do ajuizamento da ação civil pública: sendo a coletividade destinatária da tutela coletiva viabilizada pelas ações extrajudiciais do Ministério Público, essa coletividade não teria outra

${ }^{8}$ Significa, então, dizer que o inquérito civil é um instituto autônomo, apto a gerar efeitos independentemente da existência de uma futura ação civil pública. Essa autonomia deve ser levada em conta no momento em que se analisa a natureza jurídica do inquérito civil público. 
oportunidade de participação, já que na hipótese não há que se falar em "fase jurisdicional”. Assim, a coletividade não teria a oportunidade de contribuir na construção do provimento em outro momento, a não ser no próprio inquérito civil. Destarte, o inquérito civil não tem outra natureza a não ser a de processo, seguindo concepção democrática vigente no direito brasileiro. Nessa perspectiva, o paradigma de Estado Democrático de Direito e a prerrogativa de contribuição da coletividade no processo de validação do direito a ser defendido não permitem que o Ministério Público, na condução do inquérito, focalize seus esforços unicamente na pessoa do investigado. Na verdade, há duas esferas a serem investigadas no inquérito civil, a saber, (1) a lesão a bem jurídico ou direito transindividual, com a respectiva autoria, e (2) a real dimensão do direito transindividual a ser tutelado, o que só pode ser definida mediante a participação dos interessados no processo de validação.

Tem sido focalizada, até então, apenas a primeira esfera, e por esta razão é que não se tem associado ao inquérito civil o dever de se respeitar o princípio do contraditório. Verificase que as proposições deste estudo não provocam prejuízos ou burocratização dos atos instrutórios do inquérito civil, uma vez que, sendo considerada a dúplice esfera de investigação, e verificando que a segunda esfera corresponde justamente à proposta ora apresentada, admitese a atuação do Ministério Público, no âmbito do inquérito civil, mediante a implementação simultânea e paralela das investigações, de modo que uma esfera não prejudique o desenvolvimento da outra. Em outros termos, propõe-se que o Ministério Público, de um lado, investigue a ocorrência de atos ilícitos passíveis de lesão a direitos transindividuais, norteando os seus esforços na prática dos poderes instrutórios que já lhe são garantidos (primeira esfera de investigação). E de outro lado, simultânea e paralelamente, propõe-se que o Ministério Público submeta à apreciação coletiva o conteúdo do objeto de investigação, de forma que quaisquer interessados difusos possam manifestar seus interesses sobre o bem jurídico objeto de discussão (segunda esfera de investigação). Na segunda esfera, propõe-se que seja implementado um espaço de discursividade que abarque todos os princípios institutivos do processo (em especial o contraditório), sem alterar a natureza investigativa do inquérito civil.

Propõe-se que, em sendo decidido pelo ajuizamento da ação civil pública, o produto das discussões realizadas em sede de inquérito civil deverá ser incorporado à causa de pedir da ação civil pública. O interesse de agir do Ministério Público, na hipótese, dependeria da comprovação do debate e da validação do direito a ser defendido, uma vez que, em se tratando de tutela coletiva, o direito não pertence ao legitimado (exclusivamente), mas sim a toda a coletividade. Sob estes parâmetros, é possível que se vislumbre um modelo de implementação do inquérito civil de acordo com o paradigma de Estado Democrático de Direito, tornando o 
contraditório obrigatório, já que é no âmbito do inquérito civil público que se constrói a causa de pedir de eventual ação civil pública que venha a ser proposta.

Verifica-se, na atual sistemática processual, que o próprio Ministério Público poderá utilizar das provas unilateralmente produzidas no inquérito civil público para fundamentar pedido liminar de bloqueio de bens do demandado na ação civil pública, ou, também, se basear nas provas solitariamente produzidas para realizar TAC (Termo de Ajustamento de Conduta) ou, ainda, deixar de propor a ação civil pública. Todas as possibilidades alhures mencionadas causam efeitos diretos na titularidade dos direitos metaindividuais pertencentes aos interessados difusos e/ou coletivos. Em razão das premissas apresentadas, demonstra-se, de forma democrática e constitucionalizada, a indispensabilidade de observância do contraditório no inquérito civil público, de modo a assegurar a legitimidade democrática do provimento estatal.

\section{Considerações finais}

A natureza inquisitiva do procedimento investigatório que antecede a ação civil pública desobriga o Ministério Público de oportunizar o exercício do contraditório como pressuposto para a legitimidade democrática do provimento estatal. $\mathrm{Na}$ atual sistemática jurídica vigente o representante do Ministério Público possui legitimidade jurídica pressuposta na condução unilateral do inquérito civil público, possibilitando a produção solitária de provas utilizadas como parâmetro para a propositura da ação civil pública ou realização do termo de ajustamento de conduta. Nessa perspectiva teórica, impossibilita-se a participação dos interessados (difusos e coletivos) na construção dialógica do provimento estatal investigativo, ignorando-se que os efeitos jurídicos de tal provimento afetarão toda a coletividade.

A partir dos estudos desenvolvidos na presente pesquisa demonstrou-se que o contraditório é um princípio constitucional explícito, corolário do sistema participativo, e, por isso, é utilizado como referencial teórico para assegurar o efetivo direito de participação dos sujeitos afetados pelos efeitos do provimento estatal. Ou seja, a democraticidade de qualquer decisão ou atuação estatal se condiciona ao direito de toda a coletividade participar do debate processual, para que a vontade coletiva não seja reflexo das percepções unilaterais e solipsistas dos agentes públicos. É nesse contexto propositivo que foi demonstrada a indispensabilidade da observância do contraditório no inquérito civil público, como forma de possibilitar o exercício da cidadania por todos os sujeitos afetados pelo provimento estatal, desconstruindose as máximas dogmáticas já consolidadas, visto que a natureza inquisitivo-procedimental da fase investigativa tornaria inviável o exercício do contraditório. 
A teoria do processo mais difundida no Brasil, que até hoje encontra correspondência na literatura jurídica e no ordenamento jurídico atual, é a do processo como relação jurídica, que foi influenciada pelos paradigmas de Estado Liberal e Social, respectivamente, e as consequências jurídicas advindas são a definição de processo como uma relação entre as partes, na qual o juiz se posiciona em um patamar superior das partes. Tal modelo de processo não encontrou amparo na Constituição do Brasil de 1988, uma vez que o paradigma de Estado Democrático de Direito não comporta a ideia de concentração dos poderes na figura do julgador. Percebeu-se que, pela relação jurídica (também chamada de teoria instrumentalista, que vê o processo como um instrumento da jurisdição), cultivou-se a ideia de contraditório como mera oportunização da fala, sem garantir que a oportunidade de manifestação dos interessados tenha efetiva repercussão quando da elaboração do provimento final.

A assimilação do processo como um espaço (locus) de discursividade abriu caminho para uma concepção de processo, seja individual, seja coletivo, em que os verdadeiros interessados possam, de fato, contribuir para a formação do convencimento do decididor. E no âmbito do processo coletivo, é necessário que se dê lugar a um sistema participativo, a fim de que o cidadão possa influir tanto na construção participada do mérito, quanto na atuação efetiva na esfera pré-jurisdicional, nos espaços processuais existentes de defesa do direito transindividual. As ações coletivas como ações temáticas contribuem para a mudança de paradigma processual, como forma de substituição do sistema representativo vigente no ordenamento infraconstitucional pátrio, inclusive em razão da inclusão do cidadão e da coletividade no espaço de debate racional-discursivo, bem como em razão da ideia de que os direitos coletivos (e não interesses coletivos) necessitam de um processo de validação para ser reconhecidos.

O instrumento que o Ministério Público tem para proporcionar a validação do direito a ser tutelado é o inquérito civil. E sendo o inquérito civil um mecanismo constitucional de defesa de direitos transindividuais, deve ser interpretado sob o enfoque do paradigma de Estado Democrático de Direito, razão pela qual não pode ser interpretado como um instituto de natureza procedimental e inquisitiva. Considerando que o inquérito civil público visa a investigação do direito transindividual, e tendo em vista que esse direito precisa passar pela validação por parte de toda a coletividade, o instituto passa a ter natureza processual, e não de mero procedimento. A atribuição de natureza processual ao inquérito civil se baseia na perspectiva da coletividade, e não na perspectiva do investigado. $\mathrm{O}$ direito do cidadão de contribuir discursivamente para a validação do direito transindividual a ser defendido pelo Ministério Público em sede de ação civil pública faz nascer o direito de contribuição do cidadão 
e da coletividade na construção da causa de pedir da ação civil pública ou, ainda, nos fundamentos fático-jurídico-legais de realização do termo de ajustamento de conduta.

\section{Referências}

ALMEIDA, Andréa Alves de. Processualidade jurídica e legitimidade normativa. Belo Horizonte: Fórum, 2005.

ALMEIDA, Andrea Alves. Espaço jurídico processual na discursividade metalinguística. 2011. 173f. Tese (Doutorado em Direito) - Faculdade de Direito da Pontifícia Universidade Católica de Minas Gerais, Belo Horizonte.

ALMEIDA, Gregório Assagra de. Manual das ações constitucionais. Belo Horizonte: Del Rey, 2007.

ALMEIDA, Gregório Assagra de. Direito Material Coletivo: superação da summa divisio direito público e direito privado por uma nova summa divisio constitucionalizada. Belo Horizonte: Del Rey, 2008.

ALONSO JÚNIOR, Hamilton. A valoração probatória do inquérito civil e suas consequências processuais. In: MILARÉ, Edis (Coord). Ação Civil Pública: Lei 7.347/1985 - 15 anos. 2.ed. rev. atual. São Paulo: Revista dos Tribunais, 2002. p. 291-307.

ANDOLINA, Italo; VIGNERA, Giuseppe. Il fondamenti constituzionali della giustizia civile: il modello constituzionale del processo civile italiano. Torino: G. Giappichelli Editore, 1997.

ANTUNES, Paulo de Bessa. O inquérito civil (considerações críticas). In: MILARÉ, Edis (Coord). Ação Civil Pública: Lei 7.347/1985 - 15 anos. 2.ed. rev. atual. São Paulo: Revista dos Tribunais, 2002. p. 701-712

BARROS, Flaviane de Magalhães. (Re)forma do processo penal: comentários críticos dos artigos modificados pelas Leis n. 11.690/08, n. 11.719/08 e n. 11.900/09. 2.ed. Belo horizonte: Del Rey, 2009.

BEDAQUE, José Roberto dos Santos. Efetividade do processo e técnica processual. 3. ed. São Paulo: Malheiros, 2010.

BUENO, Cassio Scarpinella. Curso sistematizado de Direito Processual Civil: direito processual público e direito processual coletivo. 4. ed. São Paulo: Saraiva, 2014.

BÜLOW, Oskar Von. Teoria das Exceções e dos Pressupostos Processuais. Tradução e notas de Ricardo Rodrigues Gama. Campinas: LZN Editora, 2005.

BURLE FILHO, José Emmanuel. Ação civil pública: instrumento de educação democrática. In: MILARÉ, Edis (Coord). Ação Civil Pública: Lei 7.347/1985 - 15 anos. 2.ed. São Paulo: Revista dos Tribunais, 2002. p. 402-414.

CABRAL NETTO. Joaquim. O Ministério Público na Europa latina. Belo Horizonte: Imprensa Oficial, 1974. 
CANOTILHO, José Joaquim Gomes. Direito constitucional e teoria da constituição. 7. ed. 11 reimp. Coimbra: Almedina, 2003.

CAPPELLETTI, Mauro; GARTH, Bryant. Acesso à Justiça. Tradução de Ellen Gracie Northfleet. Porto Alegre: Fabris, 1998.

CARVALHO, Ulisses Dias de. Legitimação da atuação extrajudicial do Ministério Público: aplicação do princípio do contraditório no inquérito civil. 159f. Dissertação (Mestrado) - Programa de Pós-Graduação da Universidade Católica de Pernambuco. Recife, 2013.

CATTONI DE OLIVEIRA, Marcelo Andrade. Direito Processual Constitucional. Belo Horizonte: Mandamentos, 2001.

CHIOVENDA, Giuseppe. Instituições de Direito Processual Civil. Tradução de Paolo Capitanio. 3.ed. Campinas: Bookseller, 2002. vol. 1.

CHIOVENDA, Giuseppe. Instituições de Direito Processual Civil. Tradução de Paolo Capitanio. 3.ed. Campinas: Bookseller, 2002. vol. 2.

CHIOVENDA, Giuseppe. Instituições de Direito Processual Civil. Tradução de Paolo Capitanio. 3.ed. Campinas: Bookseller, 2002. vol. 3.

COSTA, Fabrício Veiga. Mérito Processual: a formação participada nas ações coletivas. Belo Horizonte: Arraes, 2012.

COSTA, Fabrício Veiga. Liquidez e certeza dos direitos fundamentais no processo constitucional democrática. Coleção estudos da Escola Mineira de Processo. Vol. 13. Rio de Janeiro: Lumen Juris, 2016.

COUTURE, Eduardo J. Fundamentos do direito processual civil. Traduzido por Dr. Rubens Gomes de Sousa. São Paulo: Saraiva \& Cia, 1946.

DIAS, Ronaldo Brêtas de Carvalho. Processo constitucional e Estado Democrático de Direito. 3. ed. Belo Horizonte: Del Rey, 2015.

DINAMARCO, Cândido Rangel. Instituições de Direito Processual Civil. 7.ed. São Paulo: Malheiros, 2013. vol.1.

FERES, Josan Mendes. A formação do objeto nas ações coletivas sob a perspectiva das ações temáticas: a participação direta dos interessados. 2009. 165f. Dissertação (Mestrado) Programa de pós-graduação em Direito da Pontifícia Universidade Católica de Minas Gerais. Belo Horizonte.

FERES, Josan Mendes. O processo coletivo eletrônico em rede sob a perspectiva das ações temáticas. 2016. 177f. Tese (Doutorado) - Programa de pós-graduação em Direito da Pontifícia Universidade Católica de Minas Gerais. Belo Horizonte. 
FERRAZ, Antônio Augusto Mello de Camargo. Ação civil pública, inquérito civil e Ministério Público. In: MILARÉ, Edis (Coord). Ação Civil Pública: Lei 7.347/1985 - 15 anos. 2.ed. rev. atual. São Paulo: Revista dos Tribunais, 2002. p. 84-100.

FAZZALARI, Elio. Instituições de Direito Processual. Do original: Instituzioni di diritto processuale. 8. ed. Traduzido por Elaine Nassif. Campinas: Bookseller, 2006.

FERREIRA, Juliana Maria Matos. O modelo participativo de processo coletivo: as ações coletivas como ações temáticas. 2009. 178f. Dissertação (Mestrado) - Programa de pósgraduação em Direito da Pontifícia Universidade Católica de Minas Gerais. Belo Horizonte.

FERREIRA, Juliana Maria Matos. Teoria do processo coletivo no modelo participativo. Belo Horizonte: Editora D’Plácido, 2017.

FERREIRA, Marco Aurélio Mesquita. A legitimidade ativa do cidadão para propor ação civil pública: uma proposta em defesa da efetividade dos Direitos Fundamentais. Dissertação (Mestrado) - Programa de pós-graduação em Proteção dos Direitos Fundamentais, Universidade de Itaúna. Itaúna, 2016.

FIGUEIREDO, Lúcia Valle. Ação civil pública. Ação popular. A defesa dos interesses difusos e coletivos. Posição do Ministério Público. In: WALD, Arnoldo. Aspectos polêmicos da ação civil pública. 2.ed. rev. atual. São Paulo: Saraiva, 2007. p. 233-256.

FRANÇA, Maurício Gomes Pereira. A natureza jurídica da legitimação para agir nas ações coletivas. Rio de Janeiro: Lumen Juris, 2016.

GIDI, Antonio. A Class Action como instrumento de tutela coletiva dos direitos: As ações coletivas em uma perspectiva comparada. São Paulo: Editora Revista dos Tribunais, 2007.

GOLDSCHMIDT, James. Derecho Procesal Civil. Traducción de Leonardo Prieto Castro. Barcelona: Editorial Labor, 1936.

GONÇALVES, Aroldo Plínio. Técnica processual e teoria do processo. 2. ed. Belo Horizonte: Del Rey, 2012.

GRESTA, Roberta Maia. Ação temática eleitoral: proposta para a democratização dos procedimentos judiciais eleitorais coletivos. 2014b. 257f. Dissertação (Mestrado) - Programa de Pós-Graduação em Direito da Pontifícia Universidade Católica de Minas Gerais. Belo Horizonte.

LEAL, André Cordeiro. Instrumentalidade do processo em crise. Belo Horizonte: Mandamentos, FUMEC/FCH, 2008.

LEAL, Rosemiro Pereira. Processo como teoria da lei democrática. 2. ed. Belo Horizonte: Fórum, 2017.

LEAL, Rosemiro Pereira. Teoria Geral do Processo: primeiros estudos. 14. ed. Belo Horizonte: Fórum, 2018. 
LEONEL, Ricardo de Barros. Manual do processo coletivo. 4. ed. São Paulo: Malheiros, 2017.

LIEBMAN, Enrico Tullio. Corso di diritto processuale civile. Milano: Dott. A. Giufrrè Editore, 1952.

LOPES, Edward. Discurso, texto e significação: uma teoria do interpretante. São Paulo; Cultrix, Secretaria da Cultura, Ciência e Tecnologia do Estado de São Paulo, 1978.

MAGALHÃES, Maria Luísa Costa. O processo coletivo do Estado Liberal ao Estado Democrático de Direito: da reparação do dano à prevenção do ilícito. 2016. 279f. Tese (Doutorado) - Programa de pós-graduação em Direito da Pontifícia Universidade Católica de Minas Gerais. Belo Horizonte.

MANCUSO, Rodolfo de Camargo. Ação civil pública em defesa do meio ambiente, do patrimônio cultural e dos consumidores. 10. ed. São Paulo: Revista dos Tribunais, 2007.

MANCUSO, Rodolfo de Camargo. Ação civil pública em defesa do meio ambiente, do patrimônio cultural e dos consumidores. 12. ed. São Paulo: Revista dos Tribunais, 2011.

MADEIRA, Dhenis Cruz. A cognição no Direito democrático. 2006. 228f. Dissertação (Mestrado em Direito) - Faculdade de Direito da Pontifícia Universidade Católica de Minas Gerais, Belo Horizonte.

MADEIRA, Dheniz Cruz. Tópica e processo. 2012. 551f. Tese (Doutorado) - Pontifícia Universidade Católica de Minas Gerais. Programa de Pós-graduação em Direito. Belo Horizonte.

MAZZILLI, Hugo Nigro. Pontos controvertidos sobre o inquérito civil. In: MILARÉ, Edis (Coord). Ação Civil Pública: Lei 7.347/1985 - 15 anos. 2.ed. rev. atual. São Paulo: Revista dos Tribunais, 2002. p. 308-344.

MAZZILLI, Hugo Nigro. Introdução ao Ministério Público. 6. ed. São Paulo: Saraiva, 2007.

MAZZILLI, Hugo Nigro. A defesa dos interesses difusos em juízo: meio ambiente, consumidor, patrimônio cultural, patrimônio público e outros interesses. 19. ed. São Paulo: Saraiva, 2006.

MILARÉ, Édis. A ação civil pública na nova ordem constitucional. São Paulo: Saraiva, 1990.

NUNES, Dierle José Coelho. Processo jurisdicional democrático: uma análise crítica das reformas processuais. 4. reimpr. Curitiba: Juruá, 2012.

PAOLINELLI, Camila Mattos. O ônus da prova no processo democrático. Coleção Estudos da Escola Mineira de Processo. Rio de Janeiro: Lumen Juris, 2014. vol. 3.

SACCO, Ricardo Ferreira. Constitucionalismo e Ministério Público: uma visão panorâmica. Belo Horizonte: Mandamentos, FCH/FUMEC, 2008. 
SLAIBI FILHO, Nagib. Ação declaratória de constitucionalidade. Rio de Janeiro: Forense, 2000.

ZAVASCKI, Teoria Albino. Processo coletivo: tutela de direitos coletivos e tutela coletiva de direitos. 7. ed. São Paulo: Editora Revista dos Tribunais, 2017. 